December 2011

\title{
A Plea from International Scholars of Genocide and Human Rights Studies
}

The Zoryan Institute

Follow this and additional works at: https://digitalcommons.usf.edu/gsp

\section{Recommended Citation}

The Zoryan Institute (2011) "A Plea from International Scholars of Genocide and Human Rights Studies," Genocide Studies and Prevention: An International Journal: Vol. 6: Iss. 3: Article 11.

Available at: https://digitalcommons.usf.edu/gsp/vol6/iss3/11

This Articles is brought to you for free and open access by the Open Access Journals at Digital Commons @ University of South Florida. It has been accepted for inclusion in Genocide Studies and Prevention: An International Journal by an authorized editor of Digital Commons @ University of South Florida. For more information, please contact digitalcommons@usf.edu. 


\section{A Plea from International Scholars of Genocide and Human Rights Studies}

We, the undersigned scholars, wish to express publicly our great appreciation for the International Institute for Genocide and Human Rights Studies and its parent organization, the Zoryan Institute ("the Institute"), for their thirty years of academic work in the field of genocide and human rights studies. In the face of the continuing problem of genocide in the twenty-first century, the Institute is to be commended for its service to the academic community and is recognized by scholars for providing leadership and a support structure in promoting the cause of universal human rights and the prevention of genocide.

We urgently call upon all foundations and organizations worldwide concerned with these issues, as well as individuals committed to preventing this heinous crime, to provide financial support for this world-class academic institution. If the Institute is to continue its invaluable scholarly and educational undertakings (see below), it must secure its financial foundation by raising funds for an endowment and its annual operations.

For the past thirty years, the Institute has maintained an ambitious program to collect archival documentation, conduct original research, and publish books and periodicals. It also conducts university-level educational programs in the field of Genocide and Human Rights Studies, taking a comparative and interdisciplinary approach in its examination of the Jewish Holocaust, the Cambodian Genocide, and the Rwandan Genocide, among others, using the Armenian Genocide as a point of reference. In the process, using the highest academic standards, the Institute has strived to understand the phenomenon of genocide, establish the incontestable, historical truth of the Armenian Genocide, and raise awareness of it among academics and opinion-makers.

For the past ten years, the Institute has run an annual graduate-level university course on genocide and human rights, now offered in partnership with the University of Toronto. The course provides training and support for younger scholars entering the field and helps to prepare the next generation of genocide specialists. This program fills a big gap in the university curriculum. It is unique in treating genocide not only as a historical, political, legal, and psychological study, but also by centering it within the study of human rights and by focusing on prevention.

During the last six years, in partnership with the International Association of Genocide Scholars, the Institute has published Genocide Studies and Prevention: An International Journal (GSP). Its mission is to deepen our understanding of the phenomenon of genocide, create an awareness of it as an ongoing scourge, and promote the idea of the necessity of preventing it. This highly respected journal has quickly become a leader in its field. GSP is co-published as the voice of the International Association of Genocide Scholars. This interdisciplinary, peer-reviewed journal is a resource for students, researchers, educators, practitioners, and governmental policy makers and a significant forum for scholarly discourse.

The Institute also publishes the award-winning Diaspora: A Journal of Transnational Studies, now in its twentieth year, dedicated to the multidisciplinary study of the history, culture, social structure, politics, and economics of both the traditional

"A Plea from International Scholars of Genocide and Human Rights Studies," Genocide Studies and Prevention 6, 3 (December 2011): 301-304. (C) 2011 Genocide Studies and Prevention. doi:10.3138/gsp.6.3.301 
diasporas-Armenian, Greek, and Jewish-and those transnational dispersions which in the past three decades have chosen to identify themselves as "diasporas." These encompass groups ranging from the African-American to the Ukrainian-Canadian, from the Caribbean-British to the new East and South Asian diasporas.

In an era of rapid globalization, the formal and informal power of border-crossing civil society networks is increasingly pertinent for policy makers, business leaders, scholars, and civil society. In this context, diasporas matter a great deal. They include a range of ethnic communities formed from various categories of people, such as political and war refugees, (im)migrants, and ethnic and racial minorities that have maintained a sense of collective identity away from their homeland, and they operate exemplary transnational networks between host states and homelands. While the present and potential importance of diaspora communities is gradually being recognized, the challenges they pose and the opportunities they represent for both their host countries and homelands are neither well enough understood nor sufficiently addressed. Diaspora strives to address these issues and more.

It is amazing that such an enormous effort and so many tangible results have been achieved by this institute over the past thirty years without the resources of a large university or government backing. The Institute draws heavily on volunteer efforts-all the editors of its journals are volunteers, for example-but the costs of publishing and printing are unavoidable. This work can only be achieved through the systematic and continued efforts of independent scholars, teachers, professional editors and translators, and support staff, which requires an organizational structure and appropriate financial resources. The challenge now is to guarantee the continuation of the Institute's invaluable scholarly and educational work. This will happen only if the Institute secures the required funding from those most concerned, worldwide.

We, the undersigned scholars, therefore, appeal to the global community, foundations, organizations, business leaders, and national and international institutions to show their tangible and generous support for this highly respected academic institution. We are keenly aware that the Armenian Genocide has not seen justice done, and the truth of this genocide continues to be denied. It is thus a moral responsibility that academic work continues to shed light on the Armenian Genocide and promote awareness of it through publications and university courses. It is equally a moral responsibility for the Armenian community worldwide, whose heritage of suffering has always driven the concern for other groups across the globe, to support this work generously. What better way to honor the victims of the Armenian Genocide than by bringing out the truth of this history; what better way to redeem their great suffering than to prevent other groups today from bearing the same horrific burden.

Please show your support by sending your donation today to the Zoryan Institute, which is a registered charity in both the US and Canada. Donations will receive official income tax deductible receipts. We thank you in advance for your generosity and support.

The Zoryan Institute

7 Central St., Suite 202

Arlington, MA 02476

781-646-6713

zoryanusa@aol.com
The Zoryan Institute

255 Duncan Mill Rd., Suite 310

Toronto, Canada M3B 3H9

416-250-9807

zoryan@zoryaninstitute.org 
I hereby declare that the permissions to list the names below are on file in my office. Affiliations are provided for identification purposes only.

Dr. Herbert Hirsch, Professor of Political Science and Co-Editor, Genocide Studies and Prevention

L. Douglas Wilder School of Government and Public Affairs, Virginia Commonwealth University, Richmond, VA

Varouj Aivazian, University of Toronto, Toronto, Ontario

Alex Alvarez, Northern Arizona University, Flagstaff, Arizona

Joyce Apsel, New York University, New York, New York

Yair Auron, Open University of Israel, Jerusalem, Israel

Paul R. Bartrop, Richard Stockton College of New Jersey, Galloway, New Jersey

Maja Catic, Canadian Forces College, Toronto, Ontario

Frank Chalk, Concordia University, Montreal, Quebec

Israel W. Charny, Institute on the Holocaust and Genocide, Jerusalem, Israel

Terry Cochran, Université de Montréal, Montreal, Quebec

Robin Cohen, University of Oxford, Oxford, UK

Vahakn N. Dadrian, Zoryan Institute, Conesus, New York

Alfred de Zayas, Geneva School of Diplomacy and International Relations, Geneva, Switzerland

John Evans, Former US Ambassador to Armenia, Washington, DC

Daniel Feierstein, Universidad Nacional de Tres de Febrero \& Universidad de Buenos Aires, Buenos Aires, Argentina

Amir Hassanpour, University of Toronto, Toronto, Ontario

Maureen Hiebert, University of Calgary, Calgary, Alberta

Herbert Hirsch, Virginia Commonwealth University, Richmond, Virginia

Tessa Hofmann, Freie Universität Berlin, Berlin, Germany

Rhoda E. Howard-Hassmann, Wilfrid Laurier University, Waterloo, Ontario

Adam Jones, University of British Columbia, Okanagan, British Columbia

Gregory Jusdanis, Ohio State University, Columbus, Ohio

Theodosios Kyriakidis, St. George Peristereota Research Centre, Thessaloniki, Greece

David Konstan, New York University, New York, New York

Vassilis Lambropoulos, University of Michigan, Ann Arbor, Michigan

Jason K. Levy, Virginia Commonwealth University, Richmond, Virginia

Henry Maitles, University of the West of Scotland, Ayr, UK 
Armen Marsoobian, Southern Connecticut State University, New Haven, Connecticut

Robert Melson, Purdue University, West Lafayette, Indiana

Linda Melvern, Kingston University, London, UK

Simon Payaslian, Boston University, Boston, Massachusetts

David C. Rapoport, University of California Los Angeles, Los Angeles, California

Nicholas A. Robins, North Carolina State University, Raleigh, North Carolina

William Safran, University of Colorado at Boulder, Boulder, Colorado

Eliz Sanasarian, University of Southern California, Los Angeles, California

William A. Schabas, OC MRIA, Middlesex University, London, United Kingdom

Lisa Siraganian, Southern Methodist University, Dallas, Texas

Roger W. Smith, Emeritus, College of William and Mary, Williamsburg, Virginia

Gregory Stanton, George Mason University, Arlington, Virginia

Colin Tatz, Australian National University, Canberra, Australia

Henry Theriault, Worcester State University, Worcester, Massachusetts

Khachig Tölölyan, Wesleyan University, Middletown, Connecticut

Samuel Totten, University of Arkansas, Fayetteville, Arkansas

Hannibal Travis, Florida International University College of Law, Miami, Florida

Ernesto Verdeja, University of Notre Dame, Notre Dame, Indiana

Alan Whitehorn, Royal Military College of Canada, Kingston, Ontario

Lusine Yeghiazaryan, University of São Paulo, São Paulo, Brazil 